\title{
First report of zucchini yellow mosaic virus infecting balloon flower (Platycodon grandiflorus) in Korea
}

\author{
Na-Kyeong Kim ${ }^{1} \cdot$ Hyeongjun $\mathrm{Im}^{1} \cdot$ Su Min Park ${ }^{1} \cdot$ Kwang-Yeol Yang $^{1} \cdot$ Rae-Dong Jeong $^{1}$ (i)
}

Received: 1 March 2021 / Accepted: 10 June 2021 / Published online: 16 June 2021

(c) Società Italiana di Patologia Vegetale (S.I.Pa.V.) 2021

Keywords Korea $\cdot$ Platycodon grandiflorus $\cdot$ Zucchini yellow mosaic virus

The balloon flower (Platycodon grandiflorus) is a perennial herb that grows mainly in Korea, China, and Japan. The root and leaves of the balloon flower are widely used as food and medicine due to their 3 health benefits for hypertension and diabetes (Nyakudya et al., 2014). In September 2020, virus-like symptoms such as foliar yellowing, mild mottle, mosaic, and stunting were observed in balloon flower plants on farms in Samchuck, Korea and their incidence was visually estimated to be approximately $\sim 20 \%$. To identify the causal virus, ten symptomatic and two asymptomatic balloon flower leaf samples were subjected to a DAS-ELISA using specific polyclonal antisera (Agdia, Elkhart, IN, USA) against papaya ringspot virus, pepper mottle virus, watermelon mosaic virus, zucchini yellow mosaic virus (ZYMV), cucumber mosaic virus, pepper mild mottle virus, and tobacco mosaic virus. All ten symptomatic samples were found to be positive only for ZYMV. To further confirm the presence of ZYMV, RT-PCR was conducted using ZYMV coat protein (CP)-specific primers (Cho et al. 2011). PCR products of 822 bp were amplified from five ELISApositive samples but not from asymptomatic samples. These products were then cloned into pGEM-T vector (Promega, Madison, WI); all clones were sequenced in both directions, and they showed $100 \%$ nucleotide identity among each other. The sequence of ZYMV-PG isolate from $P$. grandiflorus was deposited in GenBank (LC602261). Sequence analysis indicated that the CP gene showed $99 \%$ identity with a ZYMV isolate from the USA (MK124612). Sap from ZYMVpositive leaf samples was mechanically inoculated into ten Chenopodium amaranticolor plants. ZYMV-PG caused mild local lesions at 7 days post-inoculation. RT-PCR with the aforementioned primers verified the infection of ZYMV in all $C$. amaranticolor plants. To the best of our knowledge, this is the first report of natural infection of ZYMV in $P$. grandiflorus.

This work was supported by Korea Institute of Planning and Evaluation for Technology in Food, Agriculture, Forestry and Fisheries (IPET) through, Agriculture, Food and Rural Affairs Convergence Technologies Program for Educating Creative Global Leader Program, funded by Ministry of Agriculture, Food and Rural Affairs (MAFRA) (321,001-03).

\section{Declarations}

Ethical approval This article does not contain any studies with human participants or animals performed by any of the authors.

Conflict of interest The authors declare that they have no conflict of interest.

\section{References}

Cho J-D, Lee J-W, Ko S-J, Choi H-S, Lee S-H, Choi G-S, Kim J-S (2011) Symptoms of cucumber virus diseases occurred in Sangju and Gurye in 2006 and 2007. Res Plant Dis 17(2):196-204

Nyakudya E, Jeong JH, Lee NK, Jeong Y-S (2014) Platycosides from the roots of Platycodon grandiflorum and their health benefits. Prev Nutr Food Sci 19(2):59-68

Publisher's Note Springer Nature remains neutral with regard to jurisdictional claims in published maps and institutional affiliations.
Rae-Dong Jeong

jraed2@jnu.ac.kr

1 Department of Applied Biology, Chonnam National

University, Gwangju 61185, Korea 